\title{
Die Nederduitsch Hervormde Kerk en leervryheid, uit die geskiedenis van die Nederduitsch Hervormde Gemeente Pretoria ${ }^{1}$
}

\author{
S J Botha
}

\section{INLEIDING}

Dit is moontlik om die saak wat hier aan die orde gestel word polemies-apologeties te benader en aan die hand daarvan ' $n$ antwoord te probeer gee op die beskuldigings van leervryheid, liberalisme en modernisme, wat in die loop van meer as 'n eeu van buite teen die Nederduitsch Hervormde Kerk geslinger is ${ }^{2}$. Die benadering word egter nie gevolg nie.

In die honderd vyf en twintig jaar van die Gemeente Pretoria se bestaan het daar wel twee gevalle voorgekom waar die Kerkraad predikante moes aankla wat moontlik of werklik afwykende leerstellings gehuldig het ${ }^{3}$. Uiteindelik het dit geblyk dat die leer van die Kerk net in een geval werklik ter sake was. Beide hierdie gevalle en die houding en optrede van die Nederduitsch Hervormde Kerk sal so objektief moontlik bekyk word. Daaruit behoort dit wel duidelik te word dat die Kerk hom beslis nie daaraan skuldig gemaak het om leervryheid toe te laat nie. Selfs nie toe, deur die beskuldiging van leerdwang, gepoog is om die Kerk daartoe te beweeg nie.

Voordat by hierdie gebeure stilgestaan word, is dit wel van belang om enkele prinsipiële opmerkings oor die vraagstuk van leertug, soos dit in die reformatoriese tradisie gefigureer het, te maak.

\section{LEERTUG IN DIE KERK}

Die kerklike tug het van die begin af 'n baie belangrike plek ingeneem in die kerkordelike reëlings van die reformatoriese kerke. Trouens die kerklike tug is selfs aangemerk as die derde merkteken van die ware kerk 4 . Getrou aan die beginsel van die sola scriptura, is uit die Skrif maatreëls ten opsigte van die kerklike tug afgelei en in die belydenisskrifte en kerkordes ingeskryf. Hierdie maatreëls het nie alleen tug oor die lewe nie, maar ook tug oor die leer van die kerk, op die oog gehad.

Al die groot reformatore was dit eens dat sowel oor die suiwerheid van die lewe as oor die suiwerheid van die leer van die kerk gewaak moes word. Dit was immers hulle hele bedoeling om die verworde 
kerk in sowel leer as lewe te hervorm, met die klem veral op die leer van die kerk. Hulle het juis ten oorvloede aangetoon dat die verwording in die kerk in leer en lewe, primêr die gevolg was van die verbastering in die leer van die kerk. Daarom moes noulettend toegesien word dat die kerk by die gesonde leer sal bly. Maatreëls om dit in praktyk te bring moes dus getref word.

Hoewel Luther die regering en tug van die kerk in praktyk aan die burgerlike owerheid oorgelaat het, het hy tog aan die ander kant daarop aangedring dat tugoefening in die kerk toegepas moes word

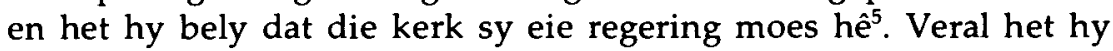
geoordeel dat daar oor die verkondiger van die evangelie toesig moes wees en dat die Skrif alleen hier die maatstaf moes wees. Die tug moes volgens hom deur die gemeente toegepas word en daarom was die gemeente

"nicht nur berechtigt, sondern verpflichtet, die Lehre des Predigers ständig zu prüfen, ob sie mit dem Wort Gottes übereinstimt.

Wo das nicht der Fall ist, kann die Gemeinde ihren Priester auch wieder absetzen"6.

Ook Zwingli het in beginsel die kerklike tug oor leer en lewe voorgestaan ${ }^{7}$. Aanvanklik het hy ook die gedagte gehuldig dat die gemeente onder leiding van die prediker, met die Skrif as maatstaf, moes oordeel oor die orde in die gemeente en ook die tug moes uitoefen. Onder die druk van die bepaalde omstandighede, het Zwingli egter al meer die tug in die hande van die burgerlike owerheid gelaat. Sy gedagte was dat waar die owerheid 'n Christelike owerheid was, die kerklike tug met gerustheid in die hande van die owerheid gelaat kon word. Hy wou dus wel die kerklike tug, maar het dit tog nie kerklik gehou nie, maar aan die owerheid oorgelaat. Daar is wel in Zurich in 1528 'n sinode ingestel wat twee maal per jaar moes vergader om die leer en lewe van elke predikant volledig te bespreek. Die predikant kon hom dan self verantwoord of verandering beloof ${ }^{8}$.

Dit was egter by uitstek Johannes Calvyn wat die beginsel dat Christus self sy kerk regeer konsekwent ontwikkel en in praktyk probeer bring het ${ }^{9}$. Hy het gestel dat die kerk nie sonder tug kon bestaan nie en daarom was die tug noodsaaklik en nuttig vir die kerk. Christus het die tug ingestel en dit dien die gemeente soos die senuwees die liggaam ${ }^{10}$. Calvyn het die grondbeginsels van die kerklike tug, soos hy dit gesien het, in sy groot werk Institutio religionis Christianae neergelê en in verskeie kerkordelike reëlings prakties uitgewerk $^{11}$. Terwyl hy die suiwere evangelieverkondiging en (die korrekte) sakramentsbediening as twee merktekens van die kerk aangedui het, het hy op 'n baie subtiele wyse die onderskeid getref 
dat die tug as merkteken nie tot die "esse" van die kerk nie, maar wel tot die "bené esse" van die kerk gereken moes word".

Aan die dienaars van die Woord het Calvyn besonder hoë eise gestel en hy het betoog dat hulle onder strenger maatreëls as die ander lidmate gestaan het ${ }^{13}$. Hulle was onderworpe aan sowel die "communis disciplina", wat vir al die lidmate gegeld het, as die "propria disciplina", wat in die besonder op hulle betrekking gehad het $^{14}$. Merkwaardig is dit egter dat Calvyn nie in die Institusie besonder breedvoerig oor die "propria disciplina" handel nie. Dit is ook eerder 'n historiese as prinsipiële betoog ${ }^{15}$. Wat die hoofsake betref, sou hy graag die praktyk van die vroeë kerk herstel wou sien. Wat hierdie hoofsake was, word deur J Plomp so saamgevat ${ }^{16}$ :

"... dat niemand tot het ambt zal worden toegelaten dan na een nougezet onderzoek met betrekking tot zijn leer en leven en dat ook ná die ordinatie opzicht en tucht over levenswandel en ambtsbediening worden uitgeoefend."

By die kerklike tug oor die leeramp, kom volgens Calvyn die sake ter sprake wat hy die "potestas Ecclessiae quoad fidei dogmata" of kortweg "potestas in doctrina" noem. Dit kan dan weer in twee onderafdelings verdeel word, naamlik die "authoritas dogmatum tradendorum" of "authoritas ad condendos fidei articulos", en die "potestas in Scripturae interpretatione"17.

Oor die "authoritas dogmatum tradendorum" handel Calvyn in die Institusie IV, 8 en 9. Die hooflyne van sy gedagtes kan saam met J Plomp soos volg opgesom word $^{18}$ :

"(a) Voor Woord van God mag niets anders worden gehouden dan de in het Oude en Nieuwen Testament geboekstaafde goddelijke openbaring. Dat Woord is de enige norm voor wat in die kerk mag worden geleerd.

(b) De kerk is niet bevoegd tot het opstellen van nieuwe geloofsartikelen (novos fidei articulos) in de zin van leerstellingen die aan de Schrift iets nieuws zouden toevoegen. Wel heeft de kerk, door de omstandigheden daartoe genoopt, meermalen leeruitspraken gedaan, maar die bedoelen niets anders dan de oorspronkelijke bedoeling van de Schrift op eenvoudige wijze te verduidelijken.

(c) Zulke leeruitspraken werden gedaan door concilies. Vooral de oude concilies verdienen hooglijk gewaardeerde te worden. Maar alle uitspraken van welke concilies ook, moeten worden beschouwd als "praeiudicia", voorlopige oordelen, die altijd opnieuw aan de regel van die Schrift getoetst moeten worden.

(d) Die uiteenzetting loopt uit op een korte conclusie: aan de kerk is geen macht gegeven om een nieuwe leer in te voeren."

Dit lyk na 'n merkwaardige slotsom in 'n hoofstuk waar Calvyn kragtens die opskrif sou handel oor die kerk se gesag om geloofsarti- 
kels te kan opstel. Wat Calvyn op die wyse skerp wou tuisbring, was dat die kerk by die opstel van 'n geloofsbelydenis uiters versigtig te werk moes gaan. Dit beteken nie dat Calvyn daarmee die opstel van geloofsartikels, as samevatting van die inhoud van die Skrif, prinsipieel afgewys het nie. Hy het self 'n geloofsbelydenis opgestel en ander ook aanbeveel om wel 'n geloofsbelydenis op te stel. Hy het dit as goed en selfs noodsaaklik beskou dat predikante wel aan 'n skriftelike formulier gebind sal word. Hiervoor het hy drie redes aangevoer, naamlik om onkunde teen te gaan, om ooreenstemming en eendrag in die leer beter tot uitdrukking te bring en ten slotte

"om de nieuwsgierigheid en de verzinsels van lieden die alleen maar vreemde dingen willen zeggen, de pas af te snijden"19.

Oor die "potestas in Scripturae interpretatione" handel hy slegs in 'n enkele paragraaf van die Institusie ${ }^{20}$. Dit hou vir hom nie in dat die kerk die gesag sou hê om die Skrif goed te keur nie. Die gesag wat die kerk wel het om die Skrif uit te lê, is vir Calvyn alleen die bevoegdheid om leergeskille by te lê. Daar is vir hom geen beter en betroubaarder geneesmiddel (nec melius nec certius remedium) om leerverskille op te los as 'n konsilie van regsinnige biskoppe wat oor die saak moet beslis nie. Aan die ander kant beteken dit nie dat hy die uitsprake van konsilies sonder meer as "vera et certa Scripturae interpretatio" beskou nie. Die kerk het wel die belofte dat die Heilige Gees leiding sal skenk, maar dwaling is nie uitgesluit nie en hoër beroep op die Skrif is altyd gewettig. Die wyse waarop die Heilige Gees die kerk lei, is egter wel dié van die gesprek of gemeenskaplike beraadslaging ${ }^{21}$.

Dit is hier ook van belang om daarop te let dat Calvyn sekere leerstukke van die kerk as noodsaaklik (necessaria) beskou het omdat hulle die eintlike leerstukke van die Christelike geloof bevat (propria religionis placita). Hy noem as voorbeelde dat daar een God is, dat Christus God is en die Seun van God, dat ons saligheid in die barmhartigheid van God geleë is. By hierdie hoofsake mag niemand 'n ander gedagte hê nie ${ }^{22}$.

Ander leerstukke wat hy "res non ita necessariae" noem, is nie so belangrik dat verskil daaroor die eenheid van geloof en belijdenis hoef te verskeur nie. Sulke kleiner verskille moet verdra word ${ }^{23}$.

Hierdie gedagtes van Calvyn is oral in Europa, waar die Calvinistiese Reformasie deurgevoer is, ook in mindere of meerdere mate toegepas. Die Nederlandse Hervormde Kerk is hiervan 'n voorbeeld, waar in beginsel en praktyk gepoog is om aan Calvyn se gedagtes oor die tug ook gestalte te gee. In beginsel is dit verwoord in die Nederlandse Geloofsbelydenis (art. 29-32), die Heidelbergse Kategismus (vrg. en antw. 85), asook in verskeie kerkordes, terwyl daar ook talle voorbeelde aangetoon kan word waar dit ook prakties toegepas is. 
Die beste voorbeeld van toepassing, is die groot Nasionale Sinode van Dordt 1618-1619, waar die leertug toegepas is en die Dordtse Leerreëls as belydenisskrif opgestel is. By die geleentheid is selfs meer as 200 predikante vanweë afwykende leerstellings afgesi ${ }^{24}$.

Reeds van vroeg af is ook in die Nederlandse Kerk van die predikante verwag om die belydenisskrifte van die Kerk te ondersteun. Dit het uiteindelik ook uitgeloop op die ondertekeningsformule wat by die Sinode van Dordt opgestel is. Die predikant moes met sy handtekening verklaar dat die drie formuliere van eenheid, die Nederlandse Geloofsbelydenis, die Heidelbergse Kategismus en die Dordtse Leerreëls "in alles met Gods Woord overeenkomen". Ook die teologiese professore, die rektore en onderwysers van skole moes hierdie formule onderteken ${ }^{25}$.

Met die opstel van die belydenisse het die kerk nie die bedoeling gehad om die Heilige Skrif kragteloos te maak nie, maar wel om uit te spreek, te bely, wat die Skrif omtrent bepaalde sake leer. Die belydenis is nie gesien as norma normans nie, maar as norma mormata, dit wil sê afgeleide reël van die geloof, ondergeskik aan die Skrif en voortdurend toetsbaar aan die Skrif wat die enigste reël van die geloof bly ${ }^{26}$. Die belydenis mag daarom nooit naas of bo die Skrif gestel word nie.

Tog is die belydenis ook reël van die geloof genoem en het dit ook gesag gehad, al was dit ook alleen 'n norma secundaria, 'n afgeleide en sekondêre gesag ${ }^{27}$. Die kerk was oortuig dat, onder die leiding van die Heilige Gees, bepaalde waarhede uit die Skrif in die belydenis as waarhede van God saamgevat is en dat dit as belydenis geglo en gehandhaaf moet word op grond van die Woord van God. Die kerk kon daarom ook nie toelaat dat die lidmate en in besonder die predikante, allerlei willekeurige en afwykende menings in die kerk huldig en verkondig nie. Sonder eenheid en suiwerheid in leer en diens, is die opbou van die kerk 'n onmoontlike saak ${ }^{28}$. Daarom kon die kerk van sy lidmate instemming met die leer van die kerk verwag en van die ampsdraers ondertekening van die belydenis as waarborg vir die regte uitoefening van hulle ampsbediening.

Dit beteken nie dat die belydenis so onfeilbaar beskou en verklaar word nie. Inteendeel, in Hervormde kring is die belydenis nog altyd beskou as elke dag toetsbaar aan die Heilige Skrif en is daar ook met betrekking tot die leertug 'n sekere ruimte gelaat.

Hierdie ruimte het in drieërlei opsig gegeld:

\section{DIE REG OM "GRAVAMINA" IN TE DIEN}

Hierdie reg het ingehou dat iemand wat twyfel of beswaar gehad het teen enige artikel van die belydenis, dit by wyse van 'n gravamen 
voor die kerk vir beoordeling kon lê. Dit kan die kerklike lewe ten goede kom en dit het persoonlike vryheid erken:

"Ieder lid der kerk heeft recht, uit Gods Woord zijn meening op te maken, maar dan heeft ook de kerk het recht, deze meening te kenne vóór iemand zijn gevoelen openbaar maakt, haar voordeel er mede te doen, of het te verwerpen, als zij bevindt, dat het met Gods Woord in strijd is"29

\section{DIE ERKENNING VAN DIE “LIBERTAS PROPHETANDI"}

Die vryheid van profesie het betrekking gehad op die gebied waaromtrent nie enige uitsprake in die belydenisse gemaak is nie. By die uitleg van die Heilige Skrif kon sulke sake soos profesieë wat nog nie vervul is nie, chronologiese, topografiese, argitektoniese, genealogiese en filologies-teologiese kwessies in aanmerking kom ${ }^{30}$. Fundamentele tekste, waaroor die kerk reeds uitsprake gemaak het, het hiervoor nie in aanmerking gekom nie. Hierdie vryheid kon in ruime mate beoefen word, mits daarvan nie misbruik gemaak word nie en steeds gehou word aan die reëls van die geloof. Dit moet erken word dat grense hier moeilik aan te wys is.

\section{DIE TOLERANSIE}

Hier was die bedoeling om die swakkeres en dwalendes tegemoet te $\mathrm{kom}$. Dit het nie gespruit uit beginselloosheid nie, maar wou alleen rekening hou met die moontlikheid dat iemand, deur gebrek aan insig, deur invloede van buite of deur vooringenomenheid, maar tog eerlik en opreg, besware kan hê teen een of meer stukke van die leer.

Hierdie dwalinge hoef dan nie goedgekeur of gehandhaaf te word nie, maar tydelik kon dit verdra en geduld word totdat dit mettertyd verbeter kon word ${ }^{31}$. Daar sou dus onderskei moes word of iemand vanweë 'n gebrek aan insig of uit onkunde gedwaal het en of hy bloot hardnekkig aan 'n bepaalde dwaallering vasgekleef het.

Om die beginsels van leertug, soos hiervoor kortliks uiteengesit, in praktyk ten uitvoer te bring, is in verskeie kerkordes van die Nederlandse Kerk maatreëls getref. Aanvanklik is die leertug met noulettendheid gehandhaaf. Mettertyd egter is leertug in die praktyk deur kerke, wat dit nog in beginsel geleer het, laat vaar. Veral sedert die begin van die negentiende eeu het leertug in praktyk agteruit gegaan $^{32}$.

Die Nederduitsch Hervormde Kerk van Afrika as historiese en regmatige voortsetting van die kerk wat deur Jan van Riebeeck na die 
Kaap oorgeplant is, het ook nog altyd in beginsel en praktyk hierdie Calvinisties-Reformatoriese gedagtes oor die leertug bly handhaaf. Uit die geskiedenis van die Gemeente Pretoria blyk dit wel duidelik.

\section{DIE BEGEMAN-SAAK 1872}

Ds Adriaan Jacob Begemann is op 27 Januarie 1861 as predikant van Pretoria georden en bevestig ${ }^{33}$. Hy het as proponent uit Nederland gekom en is nog by die Kaapse Kerk gelegitimeer. Hy was 'n goeie prediker, streng, nougeset en reguit, maar ongelukkig ook uiters ontaktvol. Hy begaan daarom allerlei foute soos die onkerkregtelike weiering om sakramente te bedien, die weiering om by twee geleenthede die sitting van die Volksraad met gebed te open en om daarenteen wel 'n nuwe Vrymesselaarslosie met gebed te open. Talle gemeentelede was met hierdie wyse van optrede baie ontevrede. Twee gemeentelede het hom selfs by die Kommissie van die Algemene Kerkvergadering aangekla oor sy gebed by die Vrymesselaarslosie. Die Kommissie het beslis dat Begemann hom nie strafbaar gemaak het deur die doen van die gebed nie, maar het tog hulle misnoeë te kenne gegee met sy wyse van optrede.

'n Groot getal gemeentelede het doodgewoon geweier om hom langer te erken as hulle predikant en die Algemene Kerkvergadering was verplig om aan hulle toe te staan om as die "Nederduitsch Hervormde Gemeente van Pretoria onder Consulentschap van de Predikant GW Smits", voort te gaan ${ }^{34}$. In die oorblywende gedeelte van die Gemeente, het die toestand gespanne gebly en trouens selfs vererger. Die saak is uiteindelik op die spits gedryf toe Begemann aan die begin van 1872 op ' $n$ uiters ontaktvolle wyse die akademiese vraagstuk van tekskritiek op die kansel gebring het.

Eers het hy in 'n privaat gesprek en 'n kerkraadsvergadering beweer dat 1 Johannes 5:7 en ook die eerste aantal verse van Johannes 8 nie in die Bybel gehoort het nie, maar later ingevoeg is. Bowendien het hy daarby ook nog gevoeg

"dat men groote oogen zoude opzetten, indien alles bekend werd wat hij wist" ${ }^{\prime 35}$.

Toe hy met hierdie gedagtes op die preekstoel kom, het die Kerkraad onmiddellik ' $n$ klag teen hom by die Kommissie van die Algemene Kerkvergadering aanhangig gemaak. Op 11 Maart 1872 het die Kommissie die volgende uitspraak gelewer ${ }^{36}$ :

"Het vraagstuk waarover gehandeld is, is niet eene questie van leer, maar van wetenschap, en de drie ouderlingen, zitting hebbende in deze Commissie en de meerderheid uitmakende, verklaren zich onbevoegd eene beslissing te nemen in zaken, 
die uitsluitend behooren tot het gebied der theologische wetenschap, en aan de godgeleerden van beroep moeten worden overgelaten.

Maar juist omdat het eene zaak van wetenschap is en door verschil van gevoelen als twyfelachtig moet worden aangemerkt, wenscht de heele Commissie van hare zijde het duidelijk te doen uitkomen, dat zij elke daad, die strekken kan om het gezag van den Bijbel bij de gemeente te verminderen, afkeurt, als zijnde gevaarlijk, ontijdig en onnoodig.

Gevaarlijk, omdat daardoor de deur wordt opengesit voor minachting van den Bijbel.

Ontijdig. De uitkomsten van de onderzoeking der Godgeleerden zij zoo twijfelachtig, en er bestaat zooveel verschil van gevoelen dienaangaande, dat het geheel ontijdig kan geacht worden, de gemeente bekend te maken met de wetenschappelijke vraagstukken die zij toch niet kan beoordeelen.

Onnoodig, omdat de Bijbel, zooals die tans voor ons ligt, en als zoodanig in de Nederduitsche Hervormde gemeente gebruikt wordt, voldoet aan die behoeften, om de weg der zaligheid te doen kennen, die voor de gemeente van het hoogste en enigste belang is om te weten.

Die Commissie wil de gebezigde woorden van den Predikant AJ Begemann als zoodanig beschouwen, daar zijn om kwaad en geen goed te doen, terwyl een dienaar van het Evangelie zich beijveren moet om te vergaderen en niet om te verstrooien, en de les van voorzichtigheid in acht te nemen, die ook in den Bijbel wordt aanbevolen."

Ten slotte het die Kommissie sy afkeuring uitgespreek oor Begemann se woorde en hom vir drie maande met verlies van traktament geskors. Bowendien moes hy die koste van die saak dra. Begemann het na sy skorsingstyd sy ontslag geneem.

Hoewel dit dus nie in hierdie saak om 'n leerkwessie gegaan het nie, kom erikele sake hier tog duidelik na vore: Die lidmate van die Nederduitsch Hervormde Kerk het die Bybel as boek met baie groot eerbied en respek beskou en hanteer. Hulle was daarom baie beslis nie gediend daarmee dat enigiemand, ook nie 'n predikant, met die Bybel op so 'n wyse sou omgaan of van die Bybel op so 'n wyse sou praat dat die Bybel en sy gesag moontlik geminag sou word nie. Die Kommissie van die Algemene Kerkvergadering se uitspraak toon dit wel duidelik. Die afleiding, op grond van hierdie saak is seker nie vergesog dat in geval van werklike dwaalleer die Kerk nog strenger sou optree nie. 
Ds CJL Ruysch van Dugteren is op 8 April 1909 bevestig as predikant van Pretoria, eers naas prof dr PJ Muller en vanaf einde 1909 as sy opvolger. By sy bevestiging het hy die volgende legitimasieformule, wat reeds sedert 1866 in die Nederduitsch Hervormde Kerk in gebruik was, onderteken ${ }^{38}$ :

"Wij ondergetekenden, predikanten van de Nederduitsch Hervormde Kerk, verklaren in goeden gemoeden, de leer welke overeenkomstig Gods Heilige Woord vervat is in de formulieren van Eenigheid der Nederduitsch Hervormde Kerk, naamlijk de Nederlandsche Geloofsbelijdenis, den Heidelbergschen Catechismus en de Dordtse Leerregelen, hartelijk te omhelzen en getrouw te zullen leeren, beloovende ons in alles overeenkomstig onze kerkelijke reglemente stiptelijk te zullen gedragen, ons onderwerpende aan het oordeel der bevoegde kerkelijke besturen alhier, indien daarteen door ons mogt gehandeld worden. De ondertekenaar van dit reglement verklaart door zijne handteekening dat hij de leer, die in bovengenoemde formulieren vervat is, gelooft overeenkomstig Gods heilig Woord te zijn."

Deur die ondertekening van hierdie formule het Van Dugteren dus uitdruklik verklaar dat hy instem met die Belydenisskrifte, dat hy glo dat dit in ooreenstemming met die Woord van God was en dat hy beloof om dit hartlik te omhels en getrou te leer. Meer as twee jaar later, op 7 Julie 1911, het Van Dugteren aan die Kommissie van die Algemene Kerkvergadering ' $n$ brief geskryf waaruit dit duidelik is dat hy in ' $n$ ernstige dilemma verkeer het omdat hy nie geglo het dat die formuliere van enigheid ten volle ooreenkomstig die Woord van God was nie. Hy het onder andere geskryf ${ }^{39}$ :

"Deze formule word door mij, bij mij in dienst - treding, ook ondertekend - over welke daad ik mij zeer bezwaard gevoel.

Om tot waarheid en helderheid te komen, zou ik gaarne van $\mathrm{u}$ vernemen hoe deze ondertekening moet worden opgevat.

Ik erken, dat op zichself deze formule duidelik genoeg is, maar toch schijnt mij ziende op histories geworden toestanden, de vraag gewettigd, of ik mij houden moet aan de letterlijke verklaring van bovengenoemde formule, zodat iedere, ook de geringste afwijking van de leer, in de drie formulieren van enigheid vervat, moet beschouwd worden als 't schenden van de belofte bij indiensttreding afgelegd - of is afwijking van de leer geoorloofd?

... Zo het uw mening mocht zijn, dat ek mij, als predikant te houden heb aan de belofte bij in dienst-treding afgelegd, dan 
voel ek mij gedrongen hier openlijk te verklaren, dat ik de leer, in de drie formulieren van Enigheid vervat, niet volkomen kan geloven overeenkomstig Gods Woord te zijn."

Dit is wel duidelik uit die brief dat Van Dugteren baie goed geweet het wat die inhoud van die formule was en wat die ondertekening daarvan beteken het. Sy probleem was dat hy in 'n onware verhouding teenoor die Kerk verkeer het. Uit persoonlike opmerkings is dit duidelik dat hy reeds by ondertekening nie geglo het soos die Kerk glo nie. Hy het dus van die begin af in 'n oneerlike verhouding teenoor die Kerk gestaan. Sy verweer hierteen was eenvoudig ${ }^{40}$ :

" $\mathrm{Bij}$ mijn indiensttreding heb ik die ondertekening opgevat als een formaliteit. - Sonder ernstig overweging heb ik getekend - ."

Na twee jaar het hierdie onware verhouding hom so beswaar dat hy besluit het om dit te erken. Hy verklaar dan ${ }^{41}$ :

"Door allerlei gebeurtenissen in mijn leven hiertoe gebracht, ben ik gaan inzien, dat ik niet het recht heb een formule, door de Kerk vastgesteld, uit te leggen, zooals ik dit wens."

Wat hy nou van die Kommissie van die Algemene Kerkvergadering wou weet, was of hy sy ondertekening letterlik moes beskou en of afwyking in die leer wel geoorloof was. Dit het feitlik daarop neergekom dat hy van die Kommissie wou weet in watter mate leervryheid in die Nederduitsch Hervormde Kerk toegelaat sou word.

Op die oog af wou dit voorkom of Van Dugteren met sy brief aan die Kommissie 'n gravamen ingedien het. Sowel uit die inhoud van die brief as uit Van Dugteren se verdere optrede blyk dit dat dit nie 'n gravamen was nie. Van Dugteren het nie in die brief op enige wyse probeer om die spesifieke gedeeltes van die formuliere van eenheid waarteen hy beswaar gehad het uit te lig en die Skrifgronde aan te dui waarop hy sy beswaar gebou het nie. Ook het hy geensins probeer aantoon dat die Kerk moontlik dwaal deur die formuliere as ooreenkomstig die Woord van God te aanvaar nie. Hy het doodgewoon verklaar dat hy nie geglo het wat hy onderteken het nie en of hy toegelaat sal word om sy ondertekening en die kerkleer te interpreteer soos hy wou. Daar was by hom ook nie die minste aanduiding dat hy bereid was om ook na die Kerk se saak te luister en moontlik tot ander oortuigings beweeg te word nie.

Ook sy verdere optrede toon dat van Dugteren self die brief nie as 'n gravamen gesien het nie. Want nog voordat die Kommissie aan die saak aandag kon gee, na hom kon luister en dan 'n beslissing kon gee, het Van Dugteren reeds op 16, 18 en 23 Julie 1911 op verskillende maniere sy besware in die Gemeente Pretoria self ter sprake gebring $^{42}$. Uiteraard het dit heelwat beroering gebring ${ }^{43}$. 
Die Kommissie kon op sy vergadering van 26 Julie 1911 ongelukkig nie 'n beslissing oor die saak neem nie, aangesien daar te min lede van die Kommissie teenwoordig was ${ }^{44}$. Die volgende besluit is nietemin tog geneem ${ }^{45}$ :

"Na lange bespreking en na een onderhoud gehad te hebben met ds CJL Ruysch van Dugteren word besloten:

1. Om niet op de zaak zelve in te gaan voor het tegenwoordige, aangezien de commissie zoo slecht ter vergadering is opgekomen;

2. aan ds CJL Ruysch van Dugteren te antwoorden: Aangezien Ds CJL Ruysch van Dugteren zich bezwaard gevoeld over zijne onderteekening van het formulier volgens art 116 en 123 der wet, welke formulier de voorwaarde bevat ter toelating tot de Evangeliebediening in de Nederduitsch Hervormde Kerk: word hem aangeraden zich van verdere prediking te onthouden, hangende het onderzoeke dezer zaak".

Aan hierdie raad het van Dugteren hom nie gesteur nie, maar op 28 Julie ' $n$ brief aan die Kerkraad van Pretoria gerig wat hy terselfdertyd in die gemeente versprei het en bowendien het hy ook op 30 Julie te Trichardtsfontein gaan preek. Hierdie optrede toon duidelik dat hy geen begrip gehad het van die Reformatoriese kerkregtelike beginsels in verband met 'n leerkwessie nie. Hy het sy afwykende gedagtes gepubliseer en verkondig en beroering veroorsaak

Uit die brief van 28 Julie word in elk geval duidelik teen watter deel van die kerkleer hy beswaar gehad het. Daarin het hy geskryf ${ }^{46}$ : "Mijn hoofdbezwaar is tegen de leer der uitverkiezing, zoals deze geleerd wordt in het eerste hoofstuk der leer van de Dordtse Leerregelen.

Hierin wordt geleerd, dat God een zekere menigte van mensen heeft uitverkoren en $\mathrm{Hij}$ naar dit besluit de harten dien uitverkorenen, hoewel zij hard zijn, genadiglik vermurwt en buigt om te geloven; maar degenen, die niet zijn uitverkoren, naar zijn rechtvaardig oordeel, in hunne boosheid en hardigheid laat. Deze verkiesing, zo wordt geleerd, is een onveranderlijk voornemen Gods, het is mij onmogelijk dit 'hartlijk te omhelzen en te leren', zoals de formule ... vereist".

Begryplik sou hy daarom ook teen artikel 16 van die Nederlandse Geloofsbelydenis beswaar moes hê. By 'n later geleentheid verklaar hy dan ook uitdruklik dat hy artikel 16 nie as volkome ooreenkomstig die Woord van God kan beskou nie. Nogtans het hy steeds nie probeer aantoon op grond waarvan die formuliere verkeerd en hy korrek sou wees. 
Op 4 Augustus 1911 het die Kerkraad van Pretoria vergader om aan die saak aandag te gee. Op die vergadering moes die Kerkraad aandag gee aan Van Dugteren se besware teen die formuliere soos hy dit in die brief van 28 Julie uiteengesit het en ook aan sy optrede tot op daardie stadium wat heelwat beroering in die Gemeente veroorsaak het. Op die vergadering self het Van Dugteren die standpunt ingeneem dat hy nie verplig was om sy ontslag as predikant te neem vanweë sy leerverskil met die Kerk nie. Daarvoor het hy twee redes aangevoer ${ }^{47}$ :

"1. Dat een gedeelte van mijn Gemeente tot nu toe niet wist, dat van hun predikanten o.a. verwacht wordt, te leren, wat staat in Art 16 van de Nederl. Geloofsbelijdenis en in het eerste hoofstuk der leer van de Dordtse Leerregelen over de uitverkiesing.

2. Heb ik gemeend niet mijn onslag te moeten nemen, omdat in onze kerk erkend zijn de gezangen, die in vele opzichten afwijken van de leer der belijdenisschriften."

Op daardie stadium het geen kerklike regeerliggaam nog enige besluit geneem dat hy sy amp moes neerlê as gevolg van sy standpunt nie. Met sy argumente wou Van Dugteren blykbaar die verwagte en feitlik vanselfsprekende skorsing en afsetting wat hom in die gesig gestaar het, voorkom. As argumente gebruik hy nou in die eerste plek die steun wat hy in sy gemeente van sommige lidmate geniet het omdat hulle van dieselfde oortuiging was as hy. Hy speel dan Gemeente en Kerk teenoor mekaar af en verklaar ${ }^{48}$ :

"Ik meen dus, ondanks de ondertekening, die ik niet handhaven kan, in de kerk te mogen blijven, tot dat mij dit verboden wordt, daar't mijn overtuiging is, dat de gemeente er niet is voor de kerk, maar de kerk voor de gemeente. Naar de gemeente moet in deze geluisterd worden".

Tweedens het hy die argument gebruik dat op grond van die feit dat onregsinnige gesange in die Nederduitsch Hervormde Kerk in gebruik was, hy ook die vryheid moes hê om die kerkleer na eie oortuiging te interpreteer.

Basies het sy argumente voor die Kerkraad op dieselfde neergekom as sy vroeëre versoek aan die Kommissie van die Algemene Kerkvergadering en dit was dat aan hom leervryheid toegestaan moes word. Volgens eie verklaring voor die Kerkraad het hy wel die grondgedagte van die leer van die uitverkiesing: God se soewereiniteit, aanvaar en was hy bereid om die evangelie van Jesus Christus te verkondig ${ }^{49}$.

"... zoals het ons gegeven wordt in het Woord van God en zooals ik het ook vindt in de Formulieren met reservering van mijn bezwaren". 
Dus het hy 'n voorwaarde daarop nagehou, wat op 'n versoek tot leervryheid vir hom, neergekom het. Hy het sy handtekening van instemming met die ondertekeningsformule, wat hom toegang tot die amp verleen het, teruggetrek maar tog gemeen dat hy steeds reg het om predikant te bly.

Die Kerkraad van Pretoria het na langdurige bespreking, tot die volgende beslissing gekom ${ }^{50}$ :

"Deze Vergadering in buitengewone vergadering te zamen gekomen ter onderzoek van Ds Ruysch van Dugteren'e verklaring van den Kansel, alsook in zijn circulaeren brief 28 Juli 1.1.

Verder overwegende dat Ds Ruysch van Dugteren in deze vergadering uitdruklik verklaard heeft: De formulieren van Eenigheid niet kan leeren en 't zelve ook niet hartelijk kan omhelzen, alsook niet gelooven, dat de formulieren van eenigheid in overeenstemming is met God's Woord;

Verder overwegende dat geen Predikant in de Herv. Kerk kan worden bevestigd, tenzij hij dit verklaren en gelooven, en aangezien Ds Ruysch van Dugteren uit eigen vrijen wil tot zulke verklaringen is overgegaan, zonder aanlijding van Kerkeraad of Gemeente

Besluit te bepalen:

1. Dat Ds Ruysch van Dugteren van af heden geen dienst meer mogen houden noch personen trouwen of Sacramenten mag bedienen.

2. Dat (hangende eventuele hooger beroep en beslissing van de Hoogere Kerkbesturen onzer Kerk) aan Ds Ruysch van Dugteren zal worden uitbetaald de helft van zijn volle traktement ingaande op hede 4 Augustus 1911 en

3. Dat zijn Eerwaarde hangende die beslissing vrijheid word gegeven de pastorie vrij te bewonen".

Die Kerkraad kon beswaarlik 'n ander beslissing geneem het, aangesien die aard van Van Dugteren se besware sodanig was dat hy nie langer op die kansel toegelaat kon word nie, anders sou dit beteken het dat leervryheid wel toegelaat word. Hom afsit kon die Kerkraad natuurlik nie, omdat dit 'n saak was wat by die Kommissie van die Algemene Kerkvergadering berus het. Bowendien is hy deur die besluit van die Kerkraad billik behandel wat traktement en huisvesting betref.

Teen die beslissing van die Kerḳraad het verskeie besware ingekom van sowel Van Dugteren self, as van sy simpatiseerders in die Gemeente. Van Dugteren self het - 'n lang "Open Brief aan de Leden der Ned. Herv. Kerk van Zuid-Afrika" gerig waarin hy homself probeer verdedig het en probeer aantoon het dat die Kerkraad buite sy bevoegdhede gehandel het. Hy het verder verklaar dat hy die 
ondertekening van die legitimasieformule as 'n blote formaliteit gesien het en dat hy vry wou wees van alle bande wat sy gewete gebind het, dus ook vry van die ondertekening van die Belydenisskrifte:

“... vrij van iedere band, die ons geweten bind, vrij van die banden, die ons maken tot machtelozen en stumpers en napraters en Farizeërs" ${ }^{\mathbf{5 1}}$.

Op 29 Augustus het hy ook aan die Kommissie van die Algemene Kerkvergadering 'n brief geskryf waarin hy ook beweer het dat die Kerkraad onregmatig opgetree het en dan vra hy ook nog pertinent van die Kommissie antwoord op die vrae ${ }^{52}$ :

"Mogen er bezwaren zijn bij de predikanten tegen de leer, vervat in de drie formulieren, ja of neen? En zo ja? Waar zijn dan de grenzen".

Uit die brief word dit duidelik dat Van Dugteren se groot probleem die slotsin van die ondertekeningsformule is:

"De ondertekenaar van dit reglement verklaart door zijne handtekening, dat hij de leer, die in bovengenoemde formulieren vervat is, gelooft overeenkomstig Gods heilige woord te zijn".

Volgens hom word met hierdie sin

"... ieder bezwaar, dat bij toetsing van de leer aan Gods Woord op mocht rijzen reeds bij boorbaat onderdrukt - en een toestand in't leven geroepen, die leiden moet tot verstening en doodsheid".

Hy sinspeel dan ook daarop dat dit neerkom op dieselfde as die Roomse leerdwang.

Weer eens wil dit voorkom of Van Dugteren geen begrip gehad het vir die Reformatoriese kerkordelike prosedures wat by 'n leerkwessie gevolg moes word nie, of nog erger, dat hy dit moedswillig ontken het. Die kerkordelike prosedure mak die toetsing van die belydenis aan die Woord van God nie onmoontlik nie; inteendeel, maar dit vereis wel 'n bepaalde prosedure. Hiervan het Van Dugteren òf geen begrip gehad nie òf hy wou hom doodgewoon nie daaraan onderwerp nie.

Op 7 en 8 September 1911 het die Kommissie van die Algemene Kerkvergadering onder die waarnemende voorsitterskap van ds MJ Goddefroy vergader om die saak te verhoor. Wat hier goed in gedagte gehou moet word is dat die Kommissie nie eers moes vasstel of Van Dugteren aan dwaalleer skuldig was of nie. Hy het immers self verklaar dat hy 'n ander leer as die Kerk voorgestaan het. Daarom is daar ook nie oor die inhoud van die leerverskil gehandel nie, maar alleen oor die vraag ò en hoe ver leervryheid in die 
Nederduitsch Hervormde Kerk toelaatbaar was. Nadat die Kommissie Van Dugteren self aangehoor het en alle ter sake stukke oorweeg het $_{4}$ is die volgende uitspraak gegee ${ }^{53}$ :

"Dat de Commissie, zelf staande onder de wet, op de vraag van ds CJL Ruysch van Dugteren, of een predikant der Nederduitsch Hervormde Kerk van Zuid-Afrika zich letterlijk moet houden, aan de formule van art 116 der wet geen ander antwoord kan geven, dan dat zij geroepen om de wet te handhaven, geene afwijking van de leer mag toelaten, en dat zij afwijkingen van de leer der drie formulieren van Eenigheid moet beschouwen als strijdig met de belofte bij de indiensttreding van een leeraar afgelegd;

Dat de Hervormde Kerk in Zuid-Afrika geene leervryheid kan toestaan en ook nooit toegestaan heeft, wat tot ontbinding der kerk zou kunnen leiden;

Dat van de predikanten verwacht wordt, dat zij zich aan hunne onderteekening zullen houden, en wanneer zij daartegen bezwaar mochten hebben dat zij dié dan brengen ter bevoegder plaatse en niet van den kansel voor de gemeente.

Dat de Commissie meent dat Ds CJL Ruysch van Dugteren door zijne verklaring dat hij zich zeer bezwaard gevoelde over zijn onderteekening van Art 116, en hij zich niet langer daaraan kan houden, zich zelve aan het predikambt in de Nederdtuisch Hervormde Kerk in Zuid-Afrika heeft onttrokken".

Drie sake is hier van belang, naamlik:

1. Afwyking van enige deel van die leer van die drie formuliere was strydig met die belofte deur die ondertekening van die legitimasieformule;

2. in die Nederduitsch Hervormde Kerk kan geen leervryheid toegelaat word nie en

3. deur hom nie te hou aan die formule wat hy onderteken het nie, het Van Dugteren homself aan die predikantsamp van die Nederduitsch Hervormde Kerk onttrek. Die oomblik toe hy sy handtekening teruggeneem het, het hy dus opgehou om predikant te wees van die Nederduitsch Hervormde Kerk.

Van Dugteren was met die uitspraak van die Kommissie nie tevrede nie en het op 13 September na die Algemene Kerkvergadering geappèlleer. Die vergadering is opgeroep vir 16 Januarie 1912, maar omdat Van Dugteren nie in ooreenstemming met artikel 138 van die geldende Kerkwet, die waarborg vir die koste van die vergadering verskaf het nie, is dit afgestel. Op 'n later stadium het die Kommissie van die Algemene Kerkvergadering besluit om Van Dugteren wel nog 'n kans te gee en het daarom die Algemene Vergadering opgeroep vir 30 April 1912 om dan Van Dugteren se appèl aan te hoor. 
Ondanks die feit dat Van Dugteren vroegtydig en behoorlik van die vergadering in kennis gestel is, was hy tog sonder verskoning afwesig. Die vergadering het daarom sonder hom voortgegaan en het ' $n$ volledige rapport van die Kommissie en ander ter sake stukke volledig en breedvoerig bespreek. Die besluit was dat Van Dugteren blykbaar deur sy afwesigheid stilswyend sy appèl teruggetrek het en hom neergelê het by die uitspraak van die Kommissie van die Algemene Kerkvergadering van 7 en 8 September 1911. Derhalwe is die uitspraak van die Kommissie bevestig.

In die Algemene Kerkvergadering self het di LE Brandt en FS du Toit verklaar dat hulle in een opsig met die Kommissierapport verskil het vir sover die beslissing was dat Van Dugteren deur die terugtrekking van sy naamtekening onder die formulier, vanself opgehou het om predikant te wees. Hulle was van mening dat hy so alleen maar kerklike tug ontwyk het en daarom was hulle van oordeel dat hy behoorlik vir sy handelswyse getug moes word en as predikant afgesit moes word. Hierdie gedagtes is egter nie verder gevoer nie.

Formeel was die Van Dugteren-saak, wat die kerklike regeerliggame betref, daarmee afgehandel. In die Gemeente Pretoria self was daar nog heelwat onrus en ontevredenheid, veral by die vriende en simpatiseerders van Van Dugteren wat hulle nie wou neerlê by die beslissing van die Kerkraad en die Kommissie van die Algemene Kerkvergadering nie. Hierdie onrus het uiteindelik gekulmineer in 'n kontrovers tussen ds MJ Goddefroy en dr HDJ Bodenstein, waarna die rus weer teruggekeer het.

\section{DIE KONTROVERS TUSSEN DS MJ GODDEGROY EN DR HDJ BODENSTEIN OOR DIE VAN DUGTEREN-SAAK}

Om hierdie kontrovers noukeurig na te gaan, is wel van die grootste betekenis. Daaruit word dit nog duideliker hoe oor die kwessie van leervryheid in die Nederduitsch Hervormde Kerk gedink is.

Terwyl die Van Dugteren-saak nog aan die gang was, is op 12 Augustus 1911 onder leiding van ' $n$ bekwame juris, dr HDJ Bodenstein, 'n lidmaat van die Gemeente Pretoria, 'n sogenaamde waaksaamheidskomitee tot stand gebring met die bedoeling om beswaar te maak teen die besluite van die Kerkraadsvergadering van 4 Augustus 1911 en om dit onder die aandag van die Gemeente te bring dat die bestaande legitimasieformule

"niet door alle predikanten gewetensvol kunnen worden onderteekend, ofschoon zij anders wel hun geloof baseren op Gods Woord" ${ }^{\prime 54}$. 
Hierdie waaksaamheidskommissie het getrag om Van Dugteren as predikant te handhaaf en selfs dat die geloofsbelydenis gewysig moes word. Na die beslissing van die Kommissie van die Algemene Kerkvergadering op 7 en 8 September 1911, het Bodenstein in November ' $n$ brosjure die lig laat sien onder die titel: Schorsing van Ds Ruysch van Dugteren: Word de Hervormde Kerk Roomsch?" Die doel van sy skrywe het hy soos volg verwoord ${ }^{55}$ :

"Verschillende redenen dringen mij tot dit schrijven, waarin ik, zoo onpartijdig als dit kan, wens te geven de gehele toedracht van de gebeurtenissen in de Hervormde Kerk - vooral de laaste maanden - die geleid hebben tot de schorsing door de Algemene Kommissie dier Kerk, van Ds Ruijsch van Dugteren, predikant van die Hervormde Kerk te Pretoria,

In die eerste plaats word ik gedrongen tot schrijven door werkelike belangstelling voor de Hervormde Kerk.

In de tweede plaats, omdat de vele geruchten, die rondgaan, getuigen van totale onbekendheid met wat er heeft plaats gegrepen - en 't mij daarom noodzakelijk toeschijnt, dat er meer licht wordt verspreid. Dit kan slechts sijn in het voordeel van waarheid en gerechtigheid - daar deze het licht niet schuwen maar daardoor gediend worden."

Hierna het hy 'n volledige oorsig gegee van die verloop van gebeure en het hy ook alle korrespondensie van Van Dugteron en besluite van die Kerkraad van Pretoria en die Kommissie van die Algemene Kerkvergadering gepubliseer. Vervolgens het hy onder drie hoofde nader op die saak ingegaan en probeer aantoon dat die besluite van die Kerkraad van Pretoria en die Kommissie van die Algemene Kerkvergadering die Nederduitsch Hervormde Kerk op die Roomse standpunt geplaas het. Die drie hoofde was naamlik: "Die Leer der Uitverkiezing, Kontraktbreuk en Geruchten."

Onder die hoof "De Leer der Uitverkiezing" ontsê hy die kerkraad die reg om Van Dugteren te kan verhinder om as predikant voort te gaan $^{56}$ :

"... en dit alleen omdat hij had beweerd, dat hij de leer der uitverkiezing, zooals geleerd in de Leerregelen van Dordt en in de Belijdenis niet volkomen overeenkomstig Gods Woord beschouwde. Let wel dat zijn standpunt niet is dat de leer van de uitverkiezing niet overeenkomstig Gods Woord is, maar nie volkomen. Met de grondbeginselen van die leer is hij het eens. Op grond van de verklaring werd hij uit de kerk gesloten als een ketter, die niet in onze kerk thuis hoort."

Voorts voer hy 'n aantal tekste aan waaruit dit volgens hom duidelik was dat die leer van die uitverkiesing, soos geleer in die Dordtse Leerreëls, nie volkome in ooreenstemming met die Woord van God 
was nie. Daarom het Van Dugteren, in ooreenstemming met artikel 7 van die Nederlandse Geloofsbelydenis, die reg gehad om die Leerreëls aan die Bybel te toets. Deur die besluite van die Kerkraad en die Kommissie van die Algemene Kerkvergadering is hierdie reg nou aan hom ontsế $\hat{e}^{57}$ :

"Dit heeft de kerkeraad gedaan en de Kommissie heeft ' $t$ goedgekeurd, alsof Ds. R.v.D. een wolf in schaapsskooi was. Stelt de Kerkeraad zich hier niet op het zuiver standpunt van de Roomse Kerk, waartegen juist de Protestanten hebben gestreden?

Wanneer wij die koers uitgaan, krijgen wij een tweede Roomse Kerk, totdat er weer martelaren en hervormers opstaan om ons te verlossen van de kerkelijke tirannie en ons weer te brengen op het zuiwer gereformeerd en protestants standpunt, nl. de Bijbel als enige richtsnoer voor het geloof en het recht van ieder individu om alle besluiten, hoe oud ook, daaraan te toetsen."

Verder het hy Goddefroy spesifiek betrek deur te verwys na uitsprake in sy De Kerkkwestie niet een Leer- maar een Levenskwestie waarin hy die klem laat val het daarop dat die belydenisskrifte nooit met die Heilige Skrif gelyk gestel mag word nie. Bodenstein betoog dan verder dat die kernvraag wat ter sprake is, die "vrijheid van geweten, een van de hoofdbeginselen van de Hervorming" was ${ }^{53}$. Die optrede van die Kommissie van die Algemene Kerkvergadering was daarom nie alleen in stryd met artikel 7 van die Nederlandse Geloofsbelydenis nie, maar gelykstaande aan dié van die Roomse inkwisisie, daarom "zuiver Roomsch", ja, selfs erger as Rooms.

Onder die hoof "Kontraktbreuk" betoog hy dat die Kommissie van die Algemene Kerkvergadering die feit dat Van Dugteren deur die terugneem van sy handtekening kontrakbreuk gepleeg het, bloot as verskoning gebruik het om hom uit die Nederduitsch Hervormde Kerk uit te kry ${ }^{59}$ :

"Dit eenmaal vasstaande bij de Kommissie, dat Ds. R.v.D. uit de kerk moest, zonder zelfs getracht te hebben hom te overtuigen van zijn dwaling ten opzichte van de leer, heeft zij een weg ingeslagen, die, wanneer ze in de Hervormde Kerk gewettigd wordt, de positie van de predikanten plaatsen zal onder die van de priesters in die Roomse Kerk. Voor mij zegt de handelinge van de Kommissie dit: Ds. R.v.D. wil vrijheid van geweten - nu moet hij tot iedere prijs uit de kerk. Dit is de indruk die de handelwijze van de Kommissie noodwendig op een onpartijdig beoordelaar maken moet, hoewel ik gaarne aanneem, dat de Kommissie dit niet heeft bedoeld." 
Juis hierdie optrede van die Kommissie van die Algemene Kerkvergadering het "Geruchten" in die Nederduitsch Hervormde Kerk laat versprei dat die Kommissie van die Algemene Kerkvergadering se uitspraak bloot gegrond was op "het haar inziens verkeerde optrede van Ds. R.v. $\mathrm{D}^{\prime \prime 60}$. Dit was geen grondige rede nie. Selfs al sou sy optrede nie heeltemal korrek gewees het nie ${ }^{61}$ :

“... dit zou nimmer een oorzaak mogen zijn hem op die wijze te behandelen, als de Kerkeraad en de Kommissie gedaan hebben. Daarover had men hem kunnen vermanen, en $\mathrm{ik}$ ben er van overtuigd dat Ds. R.v.D. iedere gerechtvaardige vermaning ten volle zou aanvaard hebben en nog zou aanvaarden."

Daarom wou hy 'n antwoord van die Kommissie van die Algemene Kerkvergadering op die vraag hê: "Waarom Ds. R.v.D. uit de Kerk gestoten?"

Goddefroy het hom verplig geag om "de toegeworpen handschoen op te nemen" en Bodenstein van ' $n$ antwoord te bedien "naar ik hoop in het belang van Land en Volk" ${ }^{\prime \prime 2}$. Hy moes die handskoen opneem vanweë die feit dat Bodenstein hom meermale beroep het op die vroeëre uitsprake van Goddefroy, maar veral ${ }^{63}$ :

"... om - ook in onze eeuw en onder ons volk - het goed recht onzer belijdende Protestantsche Kerken te helpen handhaven."

Hy het Bodenstein se herhaalde refrein: "Roomsch! Erger dan Roomsch!!!" as haatlik beskou en as blote "intimidatie" bij gebrek aan argument en "knal-effect" waar behoorlijk geschut ontbreekt" beskryf ${ }^{64}$. In sy antwoord het dit nie vir hom in die eerste plek gegaan om die besondere geval van Van Dugteren nie, maar om die beginsel wat op die spel was. Van sy vroeëre uitsprake het hy nie nodig gehad om een enkele een terug te trek nie, maar met klem het hy herhaal wat hy reeds tevore verklaar het ${ }^{65}$ :

"... dat ik steeds met heel mijn hart de gevaarlijke beginselen

van het modernisme en liberalisme openlijk heb weerstaan."

Nes vroeër beroep hy hom steeds op uitsprake van figure soos Groen van Prinsterer, Da Costa en prof dr J J van Toorenenbergen om sy eie standpunt te bevestig ${ }^{66}$. Hy antwoord dan onder vier hoofde op Bodenstein se aanval ${ }^{67}$.

i. “De aanval van Dr. Bodenstein.

ii. Het Roomsche standpunt en het Protestantsche.

iii. Gebondenheid van leden en leeraars aan Belijdenis en Belofte.

iv. Besluit."

In die eerste hoofstuk "De Aanval van Dr. Bodenstein" het Goddefroy ingegaan op die Van Dugteren-saak wat vir Bodenstein die 
aanleiding was van sy skrywe. Goddefroy het betoog dat Van Dugteren inderdaad nie "geschorst, afgezet, verstooten als een ketter" is nie, maar:

"...heeft zich self geplaats buiten de bediening des Woords in de Ned. Herv. Kerk, en heeft door woord en daad opgehouden predikant te zijn in die Kerk"68.

Dit het hy gedoen deur die terugneem van sy handtekening onder die legitimasieformule, waarmee hy hom immers oorspronklik kontraktueel aan die Nederduitsch Hervormde Kerk verbind het om die kerklike wette en belydenisskrifte te aanvaar en te gehoorsaam. Om sy standpunt te substansieer, verwys Goddefroy na artikel 53 van die Post-Acta van die Dordtse Sinode ${ }^{69}$ :

"...dat menschen die b.v. het toetsingrecht van die Kerk, in eigen hand zouden willen nemen, zich zelf moeten verbinden, om 'indien zij tegen hun eigen handteekening mochten handelen, door de eigen daad (ipso facto) gesuspendeerd zouden zijn van hunne diensten."

Hierdie selfde beginsel was reeds volgens hom in artikel 3 van die Kerkwet van die Nederduitsch Hervormde Kerk toegepas ${ }^{70}$. Daarom het hy betoog ${ }^{71)}$ :

"Al hebben wij nu niet met zoveels woorden ditzelfde formulier geteekend, het prinsipe is nooit anders onder ons geweest; en ook aangenomen in Art. 3 ten aanzien van het lidmaatschap; zonder het welke niemand Predikant kan worden."

Daarom het die Kommissie van die Algemene Kerkvergadering nie op die leerkwessie ingegaan nie. Dit was immers nie die primêre kwessie waaroor òf die Kerkraad van Pretoria of die Kommissie van die Algemene Kerkvergadering uitspraak moes gee nie, maar wel oor die vraag $^{72}$ :

"heeft een lid der Kerk en Voorganger der Gemeente, die door woord en daad zijn mandaat en kontrakt heeft verbroken, daaroor opgehouden te zijn lidmaat en leeraar der kerk? ja dan neen? $\mathrm{Zij}_{\mathrm{ij}}$ had enkel te doen met Art. $111 \mathrm{der}$ Wet - en de onderteekening daarvan."

Die vraag wat ter sake was, was dus in hoeverre'n predikant wat wel die legitimasieformule onderteken het die reg het om op 'n sekere dag van die kansel af bekend te maak $^{73}$ :

"dat hij zich niet langer kan houden aan de wettig afgelegde legitimatiebelofte; dat hij die ook beschouwt als een formaliteit; en dat hij het toetsingsrecht ten aanzien der Belijdenis zijner Kerk in eigen hand heeft genomen!"

Daarom kon die Kommissie van die Algemene Kerkvergadering geen ander beslissing gee as wat hulle wel gedoen het nie. Hulle kon 
tog nie toelaat dat 'n predikant oor die belydenisskrifte tegelyk ja en nee sê nie $^{74}$. Daarom het hy gekonkludeer ${ }^{75}$ :

"Er was maar een antwoord mogelijk. Of zou iemand, der sake kundig, hebben durven adviseeren tegen de wet en de constitutie der kerk in, feitelijk een vrijbrief uittereiken - aan wie dan ook - waardoor van de 'Gemeenschap' word gemaakt: een soort 'Nut van 't algemeen'; een 'Band van los en vast'; een lieftallig 'Allegaartje'."

Die Kommissie van die Algemene Kerkvergadering kon inderdaad nie leervryheid toelaat, wat wesenlik sou gebeur het as hulle Van Dugteren sou toelaat om sy ondertekening van die legitimasieformule te interpreteer soos hy wou nie. As Bodenstein nou betoog dat die Kommissie van die Algemene Kerkvergadering op Roomse wyse gewetensdwang toegepas het, is Goddefroy se antwoord dat Bodenstein gewetensvryheid en leervryheid met mekaar verwar ${ }^{76}$. Goddefroy het dit voorts as absoluut noodsaaklik beskou dat die Nederduitsch Hervormde Kerk juis toe meer as ooit tevore, moes waak om die belydenisskrifte wat van die vadere ontvang is, te handhaaf. Dit was immers na sy oortuiging 'n tyd "waarin de grondslagen van het christelijke maatschappelijk leven meer dan ooit te voren, worden omwoeld ..."77. Daarom het hy in die beweging rondom Van Dugteren deur diegene wat graag na hulleself as "intellektueles" verwys het, niks anders as die punt van die ysberg gesien nie $^{78}$ :

"Mag ik vragen in alle bescheidenheid aan die menschen, die sich bij voorkeur 'intellectuelen'achten, of iemand hunner zoo argeloos is te meenen, dat de bestrijding van de Kerkelijke formuleering der Praedestinatie, nu het eigenlijke einddoel is dier beweging, thans in Pretoria zoo breed op touw gezet? Ligt niet alreeds bij velen de bijl aan de wortel van andere boomen? Hoe staat het bij vele intellectuelen b.v. met de leer der Onschendbaarheid der H. Schrift, als het Woord van God? Hoe moet de leer der $\mathrm{H}$. Drievuldigheid; der Verzoening door het bloed van Christus; der Godheid des Zoons? der opstanding des vleesches, rechtvaardig oordeel en eeuwig leven?

Zijn niet deze leerstukken voor de meeste 'intellectuelen' als zovele vraagtekens, waarvan zijn maar weinig of geen notitie hebben genomen?"

In die tweede hoofstuk handel Goddefroy oor "Het Roomsche standpunt en Het Protestantsche". Hy stel die Roomse standpunt korliks soos volg ${ }^{79}$ :

"De Roomsch Catholieke Kerk leert: dat zij de éénig ware Kerk is; en dat buiten haar geen zaligheid is te verkrijgen; dat de Pous van Rome, als opvolger van Petrus en plaatsvervanger van 
Christus in geloofs en gewetenszaken eenvoudig heeft te gebieden; en zijne uitspraken als onfeilbaar moeten worden geëerd en gevolgd; dat de geestelijke macht hooger is dan de wereldlijke, en de Pous derhalve iemand kan ontslaan van alle gehoorsaamheid en belofte eenmaal afgelegd; dat de $\mathrm{H}$ Schriften niet toereikende zijn tot onderricht; en de overlevering evenveel als Gods Woord moet worden geacht, en onvoorwaardelijk geloofd."

Hierdie standpunt het hulle in hulle spesifieke belydenisskrifte soos die besluite van die Konsilie van Trente, die Professio Fidei en die Roomse Kategismus verwoord. Hierteenoor leer die Protestantse kerke die volgende ${ }^{80}$ :

“dat het Woord van God de éénige richtsnoer is van 'geloof en leven'; dat wij ons alleen aan onzen Heere Jezus Christus te houden hebben tot zaligheid; en dat wij, zonder eenig toedoen van goede werken, alléén uit Genade door het geloof in Hem, gerechtvaardigd en zalig worden. Ook: dat de zaligheid niet afhangt van eenige uiterlijke Kerkgemeenschap; en de ware Kerk daar is te vinden waar Gods Woord rein en zuiver wordt gepredikt, en de Sacramenten bediend, naar de instelling van Christus. Ook erkennen zij geen menschelijke gezag over het geweten. ..."

Hierdie standpunte van die Protestantse kerke het hulle op hulle beurt elkeen vasgelê in die spesifieke belydenisskrifte soos in Duitsland die Confessio Augustana ensovoorts en in Nederland die Nederlandse Geloofsbelydenis, die Heidelbergse Kategismus en die Dordtse Leerreëls.

Vervolgens beroep Goddefroy hom volledig op die standpunt van Groen van Prinsterer in verband met die Protestantse toetsingsreg en haal hy uitvoerig uitsprake van Groen aan. Die Protestante het net soos die Roomses geloofseenheid verlang en daarom het hulle ook geëis ${ }^{81}$ :

"onderwerping aan de Belijdenis der Kerk omdat zij Bijbelsch, onderwerping aan de Bijbel omdat deze Goddelijk is."

In die Protestantse kerke kan die belydenisskrifte wel getoets word maar dan moet die volgende in gedagte gehou word ${ }^{82}$ :

"Het recht van onderzoek, waarin doorgaans, zonder eenige zinsbeperking, het wesen der Hervorming wordt gesteld, is, krachtens haar beginsels, zeer verschillend naar mate het, voor ieder mensch, voor ieder Christen, voor ieder lid van een Kerkgemeenschap ingeroepen word. 
Voor de mensch tegenover medemenschen is het recht van onderzoek onbeperkt; de gewetensvrijheid volkomen; niemand is bevoegd anderen tot aanneming van zijn geloof en denkwijs te dwingen. ...

Voor den Christen is het onderzoek binnen de grenzen der Openbaring beperkt. Doch juist omdat hij aan haar uitspraak gehouden is, is hij gerechtigd en verpligt al wat hem wordt voorgedragen van hoedanig menschelijke gezag ook voorzien, met de H. Schrift te vergelijken. De Bijbel is proefsteen! Hierdoor worden Kerkvergaderingen en Kerkelijke leerstellingen niet van invloed beroofd, maar de invloed wordt geregeld door de hoogste wet der Christelijke Kerk. Eindelijk: ieder lid eener bijzonder kerk is, in die hoedanigheid, tot eerbiediging dier grondslagen van het genootschap gehouden. Hiertoe zijn de leeraars in dubbele mate verplicht, wier gezag willekeurig is, wanneer het nie ondergeschikt blijft aan het gezag der Kerk waarvan zij leden en dienaren zijn. Verklaring van onvoorwaardelijk geloof aan den Bijbel wordt van den Christen verlangd. Verklaring van gevoelens omtrent hoofzakelijken inhoud van den Bijbel, is bij elk protestantsch kerkgenootskap als onmisbaar vereischte, tot grondslag gelegd."

Die bewering dat die Protestantse kerke, deur die aanvaarding van formuliere, hulle eie beginsels prysgegee het, is 'n misvatting en verdagmaking deur diegene wat die menslike rede as die oppergesag oor alles poneer. Hierteenoor moet duidelik gestel word dat ${ }^{83}$ :

"De grondslag van de Kerkhervorming is geenzins teugelloze vrijheid geweest. $\mathrm{Zij}$ heeft, met verbanning van gewetensdwang, de vrijheid der meeningen binnen den kring der grondwaarheden beperkt; eenheid en behoud evenzeer als vrije beweging en ontwikkeling, gewild."

As 'n predikant of lidmaat dan nie met die spesifieke formuliere kan instem as in ooreenstemming met die Woord van God nie, dan moes hy eerlikheidshalwe daardie kerkgenootskap verlaat.

Hoofstuk III dra die titel "Gebondenheid van Leeraars en Leden aan eigen Belijdenis en Belofte". Hier word Goddefroy se standpunt in die volgende aanhaling kort teruggevind ${ }^{84}$ :

"Tegenover 'Kerkgezag en gewetensdwang' van Rome stellen de Kerken der Hervorming 'gebondenheid aan eigen Belijdenis en Belofte'.

Is dit zoo onredelijk?

Waar Rome gezag uitoefent over de gewetens der menschen; haar Belijdenis van boven af oplegt en decreteert; en de Belijdenis desnoods te vuur en te zwaard op de keel drukt harer leden! daar vraagt de Hervormde Kerk niets anders (niets meer maar 
ook niets minder) dan eerlijke uitvoering van eigen belofte en kontrakt, gemaakt ten aanzien van de uitdrukking van het geloof der gemeenschap, neergelegd in de Formulieren; opgemaakt door de wettige daartoe verkozen vertegenwoordigers der Gemeente."

Daarom is die grondslag van die Nederduitsch Hervormde Kerk en van sy belydenis ${ }^{85}$ :

"... noch de opperheerschappij van het mensch verheffen Rome; maar enkel dié van het Godgeopenbaarde Woord."

Maar juis daarom kan met die belydenis, wat wel nie in sigself onfeilbaar is nie, nie na willekeur omgegaan word met die houding ${ }^{86}$

"ik zal deze in de Kerk; van den Kansel, en overal waar het mij behaagt: behandelen, verklaren en uitleggen, naar eigen meening, inzicht en goeddunken! ' $k$ ' de onfeilbare! 'I $k$ ' de souvereine Macht! ... Dat nooit!"

'n Quatenus-standpunt, wat neerkom op ' $n$ voorwaardelike ondertekening van die legitimasieformule, is daarom eenvoudig onsin. Dit kom vir Goddefroy neer op die Jesuitiese "reservatio mentalis" en hy stel dan die vraag ${ }^{87}$ :

"Wie loopt gevaar Roomsch te worden, de Hervormde kerk of Dr. B.? En dat nog wel Jesuitisch Roomsch!"

In die laaste hoofstuk konkludeer Goddefroy dat die optrede van Van Dugteren en sy volgelinge geensins waardeer kan word nie. Alhoewel die leerkwessie nie aan die orde gestel is by die Van Dugteren-saak in die Kerk nie, stel Goddefroy dit onomwonde dat die leer van die uitverkiesing nie maar net 'n geringe saak was, soos Bodenstein wou voorgee nie, maar inderdaad die hart van die $\mathrm{Kerk}^{88}$. Goddefroy vind dit ook "wonderbaar vreemd" dat Bodenstein van mening was dat die leer van die uitverkiesing spesiaal by die Gereformeerde Kerk alleen sou tuishoort. Dit was immers die gemeenskaplike besit van al drie die Hollands-Afrikaanse kerke en daarom al drie se roeping en plig om dit te handhaaf ter wille van land en volk ${ }^{39}$. Alles in aanmerking genome het Van Dugteren en sy volgelinge op 'n totaal ander standpunt gestaan as die Nederduitsch Hervormde Kerk en daarom was dit ongewens, onmoontlik en onhoudbaar om hulle onder een kerklike dak saam te probeer hou ${ }^{90}$. Ten slotte toon hy dan aan, deur ' $n$ vergelyking van die gedagtes van Van Dugteren en dié van 'n moderne teoloog soos Moltzer, dat Van Dugteren ten slotte ook daarby sal moet kom om die Bybel self en die belydenisskrifte as papierpouse te verwerp ${ }^{91}$.

Goddefroy het met sy antwoord op die aanvalle van Bodenstein 'n groot diens aan die Nederduitsch Hervormde Kerk gelewer en duidelik aangetoon dat die Nederdtuisch Hervormde Kerk geen leervryheid kon toelaat of toegelaat het nie ${ }^{92}$. 
Dit kan gestel word dat hierdie brosjure van Goddefroy weer eens baie duidelik die suiwer Reformatoriese standpunt van die Nederduitsch Hervormde Kerk gestel het. Hierdie brosjure, wat deesdae nie meer bekend is nie, is een van die vaste bakens wat Goddefroy geplant het. Daar is weinig ander geskrifte bekend waar die verhouding van Skrif, belydenisskrif en kerklike orde èn die dienaar van die Woord se verantwoordelikheid ten opsigte van die drie sake, so helder en duidelik uiteengesit word.

\section{Aantekeninge}

1. Die artikels in hierdie uitgawe is die lesings gehou voor die kongres van die Kerkhistoriese Genootskap van die Nederduitsch Hervormde Kerk van Afrika op 11. November 1981 te Pretoria.

2. Ds Frans Lion Cachet het met hierdie beskuldiging begin en dit is daarna voortgesit deur di JP Jooste, HS Bosman en verskeie ander. Ook GD. Scholtz het in sy: Die Geskiedenis oor die Nederduitse Hervormde of Gereformeerde Kerk van Suid-Afrika 1842-1885, Kaapstad 1956, daarmee voortgegaan.

3. Ds MJ Goddefroy is wel van buite die Nederduitsch Hervormde Kerk van leervryheid beskuldig deur ds HS Bosman. Dit was egter valse en kwaadwillige beskuldigings van Bosman waarteen Goddefroy homself afdoende vereer het. Sien SJ Botha, Ds Marié Joséph Goddefroy 1948-1920. Sy Lewe en Betekenis, ongepubliseerde DD Proefskrif, Universiteit Pretoria, 1980, bl 146-164.

4. Nederlandse Geloofsbelydenis, Artikel 29.

5. H Bouwman: De Kerkelijke Tucht, Kampen 1912, bl 62-69.

6. J Hovius: Het Toezicht op de Dienaren des Woords door de Kerkelijke vergaderingen, Vlaardingen 1968, bl 11 en J Plomp: De Kerkelijke Tucht Bij Calvijn, Kampen 1969, bl 56.

7. H Bouwman: aw, bl 70-72 en J Plomp: aw, bl 56.

8. J Plomp: aw, bl 56.

9. J Plomp: aw, bl 62 vv en H Bouwman: aw, bl 72 vv.

10. J Plomp: aw, bl 122-123.

11. J Calvinus: Institutio Christianae Religionis, IV en J Plomp, aw, bl 137 vv.

12. J Plomp: aw, bl 127.

13. J Calvinus: Institutio, IV, 12,22.

14. J Calvinus, Institutio, IV, 12,1 en J Plomp: aw, bl 250

15. J Plomp, aw, bl 251.

16. J Plomp, aw, bl 253.

17. J Plomp, aw, bl 255-7.

18. J Plomp, aw, bl 256.

19. J Plomp, aw, bl 257.

20. J Calvinus, Institutio, IV, 9,13.

21. J Plomp: aw, bl 259.

22. J Calvinus: Institutio, IV, 1,12.

23. J Calvinus: Institutio, IV, 1,12.

24. H Bouwman: aw, bl 126.

25. GA Kersten: Kerkelijk Handboekje, Utrecht 1961, bl 201, 209, 213 en 214.

26. H Bouwman: aw, bl 183.

27. H Bouwman: aw, bl 187.

28. H Bouwman: aw, bl 187.

29. H Bouwman: aw, bl 188.

30. H Bouwman: aw, bl 189.

31. H Bouwman: aw, bl 191-192.

32. H Bouwman: aw, bl 179. 
33. Sien oor Begemann: SJ Botha; Begemann, Adriaan Jacob in Suid-Afrikaanse biografiese Woordeboek, Deel I, Eerste uitgawe, Kaapstad, 1968, bl 63.

34. SM Engelbrecht: Geskiedenis van die Nederduitsch Hervormde Kerk van Afrika, Derde druk, Pretoria-Kaapstad 1953, bl 251 vv.

SP Engelbrecht: Die Nederduitsch Hervormde Gemeente Pretoria 1855-1955, Uitgegee deur Kerkraad 1955, bl 52.

HM Rex: e.a., Nederduitsch Hervormde Gemeente Bronkhorstspruit 1869-1969, Krugersdorp 1969.

35. SP Engelbrecht: Pretoria, bl 41.

36. SP Engelbrecht: Pretoria, bl 42.

37. Wat hier volg oor die Ruysch van Dugteren-saak is vir die grootste deel woordeliks geneem uit my proefskrif. SJ Botha, Goddefroy, bl 365-383.

Sien oor die Ruysch van Dugterensaak ook nog HT van Deventer: Die Leertug in die Nederduitsch Hervormde Kerk van Afrika, Ongepubliseerde BD-Skripsie, Universiteit van Pretoria, 1971.

38. Hierdie formule is deur di Van der Hoff en Begemann opgestel en in Februarie 1866 deur die Algemene Kerkvergadering bekragtig. Van Dugteren self het later beweer dat hy die formule nie dieselfde dag van sy bevestiging onderteken het nie, maar eers 'n paar maande later. Dit is egter ' $n$ feit dat sy handtekening wel onder die formule staan en dat hy eiehandig die betrokke datum ingeskryf het.

39. Nederduitsch Hervormde Kerkargief, A 11/F/C.

40. HDJ Bodenstein: Word de Hervormde Kerk Rooms, Pretoria 1911, bl 6.

41. HDJ Bodenstein, aw, bl 6.

42. Sien SP Engelbrecht, Geskiedenis, bl 371.

43. Reeds op 10 Julie 1911 het vyf kerkraadslede, nl FA Smith, J Boerstra, CJ Erasmus, FJ Loggrenberg en MJ van der Westhuizen ' $n$ brief aan die Kommissie van die Algemene Kerkvergadering gerig met die versoek dat Van Dugteren nie verder tot die kansel toegelaat word nie. Omdat hulle nie ooreenkomstig die kerkwet hulle beswaar en versoek eers by die Kerkraad ingedien het nie, moes die Kommissie van die Algemene Kerkvergadering die brief na hulle terug verwys. Sien Notule Kommissie van die Algemene Kerkvergadering, 26 Julie 1911.

44. Slegs die drie predikantslede naamlik CW du Toit, Van Belkum en Goddefroy en een ouderling was teenwoordig.

45. Notule Kommissie van die Algemene Kerkvergadering, 26 Julie 1911.

46. HDJ Bodenstein: aw, bl 7.

47. HDJ Bodenstein: aw, bl 7.

48. HDJ Bodenstein: aw, bl 8 .

49. HDJ Bodenstein: aw, bl 9.

50. Notule Kerkraad Pretoria: 4 Augustus 1911.

51. Hierdie brief is ook volledig te vind in HDJ Bodenstein: aw, bl 4-11.

52. Notule Kommissie van dis Algemene Kerkvergadering: 7 tot 8 September 1911. Wat die besluit van die kerkraadsvergadering van Pretoria van 4 Augustus 1911 betref, het die Kommissie van die Algemene Kerkvergadering beslis:

"... dat ds Ruysch van Dugteren door het terugnemen van zijne handtekening zich buiten de kerk heeft gesloten, en daardoor heeft opgehouden dienstdoend predikant der Nederduitsch Hervormde Kerk te zijn, ... te handhaven dat deel van het besluit van de Kerkraad van Pretoria d.d. 4 Augustus, dat ds Ruysch van Dugtern het verrichten van zijn diensten belet;

en dat met betrekking tot punt 21 het geven van half salaris aan de predikant, de Commissie beslist, dat het salaris tot op 7 September zal worden uitbetaald;

De Commissie vind het prijsenswaardig dat de Kerkeraad ds Ruysch het bewonen der pastorie heeft toegestaan."

Sien ook De Hervormer: 15 September 1911.

53. Onder leiding van Bodenstein het ' $n$ byeenkoms van ' $n$ aantal gemeentelede op dié datum plaasgevind en die volgende besluite geneem:

"Deze vergadering van gemeenteleden van Pretoria, vernomen hebbende, dat de Eerw. Kerkeraad op de vergadering van 4 Aug 1.1. besloten heeft, Ds Ruysch van Dugteren voorlopig te verhinderen als leraar van de Gemeente op te treden en 
mede besloten heeft het salaris van $Z$ Eerw te verminderen, betreurt zodanig besluit ten zeerste, alz zijn de in strijd met die bepalingen van de Kerkwet, die de Kerkeraad geen meerdere bevoegdheid verleent dan verwijzing van een zaak als die van Ds $R$ van Dugteren, naar de Algemene Kommissie.

Verder geeft deze vergadering, ziende de sympathie, betuigd door een groot deel van de Gemeente met het beginsel van Ds R v D, uiting aan de wens, dat de geloofsbelijdenis, vervat in de formule, vermeld in Art. 116 van de Kerkwet, die een predikant bij zijn beroepen aanvaarden ter onderteekening word voorgelegd, worde gewijzigd, daar gebleken is, dat de tans bestaande "Drie Formulieren van Enigheid", die een Predikant moet ondertekenen, als zijnde volkomen in overeenstemming met Gods Woord, niet door alle predikanten gewetensvol kunnen worden ondertekend, of schoon $\mathrm{zij}$ anders wel hun geloof baseren op Gods Woord."

Die waaksaamheidskomitee wat by die geleentheid gekies is het bestaan uit Bodenstein, D van Warmelo, L Geers, M Hollebrands en JH de Loor. Hulle wou juis die besware onder aandag van die gemeente bring omdat hulle van mening was dat:

(1) het besluit van de Kerkeraad onwettig was,

(2) dat het besluit van de kerkeraad op onbehoorlike wijze invloed zou uitoefenen op de beslissing van de Algemene Kommissie en

(3) omdat de leden van de Gemeente meenden het recht te hebben zich uit te spreken over de handelwijze van de kerkeraad die zij als haar lasthebbers beschouwt."

Sien HDJ Bodenstein, aw, bl 27.

55. HDJ Bodenstein, aw, bl 1.

56. HDJ Bodenstein, aw, bl 28.

57. HDJ Bodenstein, aw, bl 30.

58. HDJ Bodenstein, aw, bl 33.

59. HDJ Bodenstein, aw, bl 36-37.

60. HDJ Bodenstein, aw, bl 37.

61. HDJ Bodenstein, aw, bl 37.

62. MJ Goddefroy, Neen niet Roomsch!, Pretoria 1912, bl 3.

63. MJ Goddefroy, Neen niet Roomsch!, bl 4.

64. MJ Goddefroy, Neen niet Roomsch!, bl 4.

65. MJ Goddefroy, Neen niet Roomsch!, bl 6. Hy verklaar wel dat die rolle intussen omgekeer is:

"Wel zijn de rollen thans omgekeerd! Toen werd een 'Hollanderpredikant' aangevallen om de 'Kerk'; en de alarmklok geluid wegens vermeende onzuiverheid in de leer; Tans wordt de 'Kerk' aangevallen om een 'Hollanderpredikant'; en de grote klok geluid, wegens vermeende overdreven handhaving van de leer!

Nou, 't Kan verkeeren!' zei Brederô." (bl 4).

66. Hy haal die bepaalde uitsprake volledig aan. Sien MJ Goddefroy, Neen niet Roomsch!, bl 5.

67. MJ Goddefroy, Neen niet Roomsch!, bl 6.

68. MJ Goddefroy, Neen niet Roomsch!, bl 8.

69. MJ Goddefroy, Neen niet Roomsch!, bl 10.

70. Artikel 3 van die kerkwet het soos volg gelui:

"Deze allen blijven tot de Nederduitsch Hervormde Kerk behooren, zoolang zij niet door woord of daad ten duidelijkste toonen, zich van haar af te scheiden, of zoolang zij zich niet der kerkelijke gemeenschap hebben onwaardig gemaakt."

71. MJ Goddefroy, Neen niet Roomsch!, bl 10.

72. M] Goddefroy, Neen niet Roomsch!, bl 10. Goddefroy het ook gestel:

"Immers het punt in geschil tusschen den Predikant van Pretoria, Ds. R.v.D. en zijn kerkeraad liep niet over de leer der uitverkiezing zooals geformuleerd in onze Belijdenisschriften - maar over de beteekenis en kracht van de 'legitimatieformule', door de wet geëischt voor de predikanten der Ned. Herv. Kerk."

73. MJ Goddefroy, Neen niet Roomsch!, bl 10.

74. Goddefroy het dit so gestel: 
"Welke vereeniging, maatschappij of genootschap kan of mag toelaten dat een harer leden tegelijkertijd 'ja en neen' zegd over dezelfde zaak; zijn eigen opinie stelt in de plaats van dié zijner Kerk, en een grondwet aanvaardt, 'onder persoonlijke restrikties'."

MJ Goddefroy, Neen niet Roomsch!, bl 10.

75. MJ Goddefroy, Neen niet Roomsch!, bl 13.

76. Met verwysing na Bodenstein se argument dat gewetensvryheid juis een van die vrugte van die Reformasie was, stel Goddefroy:

“... door innige behoefte en brandende dorst naar ' $t$ levend geloof, dat vruchten draagt der bekeering waardig, hebben de Protestantsche vorsten en volken ' $g$ ewetensurijheid' bekomen; maar gewetensurijheid beteekende in die dagen vrijheid van godsdienst voor elk en een isgelijk; maar was nooit en nergens synoniem met 'leerorijheid' gelijk eens in onzen tijd wordt gedacht."

M] Goddefroy, Neen niet Roomsch!, bl 12.

77. M] Goddefroy, Neen niet Roomsch!, bl 11.

78. M] Goddefroy, Neen niet Roomsch!, bl 11.

79. MJ Goddefroy, Neen niet Roomsch!, bl 15.

80. M] Goddefroy, Neen niet Roomsch!, bl 16.

81. M] Goddefroy, Neen niet Roomsch!, bl 17.

82. M] Goddefroy, Neen niet Roomsch!, bl 17-18.

83. MJ Goddefroy, Neen niet Roomsch!, bl 19.

84. MJ Goddefroy, Neen niet Roomsch!, bl 21.

85. MJ Goddefroy, Neen niet Roomsch!, bl 22.

86. MJ Goddefroy, Neen niet Roomsch!, bl 22.

87. MJ Goddefroy, Neen niet Roomsch!, bl 22.

88. M] Goddefroy, Neen niet Roomsch!, bl 26.

89. MJ Goddefroy, Neen niet Roomsch!, bl 27.

90. MJ Goddefroy, Neen niet Roomsch!, bl 28.

91. M] Goddefroy, Neen niet Roomsch!, bl 29 vvm.

By die Nederduitsch Hervormde Kerk was daar waardering vir Goddefroy se antwoord. Die Kommissie van die Algemene Kerkvergadering het daarom by sy vergadering van 14 Augustus 1912 Goddefroy bedank omdat hy die Kerk verdedig het en besluit om die boekie van harte aan te beveel. 